\title{
The quality of the public open space in Engure village in Latvia
}

\author{
Anna Kalniņa, Natalija N̦itavska, Latvia University of Agriculture
}

\begin{abstract}
The role and significance of the public open space in the world in the context of urban and populated areas is increasing and becoming important among both for professionals of related areas and for the population. The relevance of this topic in Latvia has also increased in recent years. Public open space is one of the most important aspects of the quality of the living environment, which affects the economic and sociological factors of the place. It creates the identity of the place and characterizes the society that makes it and resides there. The public open space of Engure village is evaluated in the research. Engure village is one of the coastal fishing villages in Latvia, which was formed in the $2^{\text {nd }}$ half of the $13^{\text {th }}$ century, later developing as one of the small port villages on the western coast of the Gulf of Riga. There are about 1500 inhabitants in Engure, but in the summer season, the village becomes a favorite destination for tourists and holidaymakers. Using the comparative method for the analysis of the scientific literature in the research, main determining factors of the public open space were defined and the basic criteria for the assessment of the quality, accessibility and functionality of the open space were selected. Through the evaluation of the public open space of the village, gained results reflect the quality of the public open space of Engure village, which is characterized by the availability of the place, the overall evaluation of general improvement, the greenery and the environmental quality.
\end{abstract}

Keywords: public open space, quality, accessibility, coastal landscape

\section{Introduction}

The public open space is a freely available area and space for everyone. Such public areas as streets, boulevards, roads, squares, parks, city gardens, courtyards, embankments, passages, promenades and other places that have been placed for public use irrespectively of their property ownership are considered as a public open space [15]. The public open space forms in dependence to various changes and processes that take place in the placesociological, political or economic. The factors that determine the frequency of the use of a place are its quality, which includes the location in the populated area and its function, accessibility, approachability, shape, size, aesthetic quality and attractiveness, views, climate and elementsof amenities $[8 ; 7 ; 6]$. The quality of the public open space is regarded as an important urban environmental factor, as the public open space itself is one of the main basic elements of the structure of this environmental landscape. In the same way, with its functionality and a set of activities possible to do in the place, it is a significant indicator of the quality of living environment of the surrounding population, the basis of mental and physical health [12].

One of the most urgent issues in researches of the public open space in recent years is how to evaluate the most important of the public open space determining factors, which should be considered as the basic factors determining the quality of the public open space and how to evaluate these factors. According to the research conducted by PPS (nonprofit organization "Project for public space"), the four basic factors that make up the public open space are defined accessibility, comfort or environmental quality, function and social environment $[9 ; 16]$.

In rural areas, the role of the public open space is more economical than recreational, it is an open space where trade takes place - in the markets and in storefronts, or events, it is a place of rendezvous that solves necessary everyday needs, such as moving from work to home, waiting. Nature territories that are characterized to the structure of rural settlements, are mainly used for recreation, forming the uniqueness, identity of the place, natural, cultural and historical values, on the basis of which hiking trails and natural tourism objects as public open spaces are being developed, which becomes a significant contributor to the economic factors of a local municipality [10]. The public open space is not only a place for society activities and the provision of functional needs, but it also forms a general visual image and identity of a populated area, characterizing the populated area, its inhabitants, traditions and values. In the absence of the public life and the public open space, the emotional connection of the inhabitants to the place is reduced $[11 ; 2]$.

By providing the satisfaction of some physical and psychological needs of every individual who visits and resides in the public open space, promoting the improvement of the quality of the living environment to the populated area as a whole, the public open space creates the economic and social common benefit that refers both to every citizen and visitors of the place, as well as to the populated area as a whole. Three main factors determining the quality of the populated area are the physical, economic and social environment. 


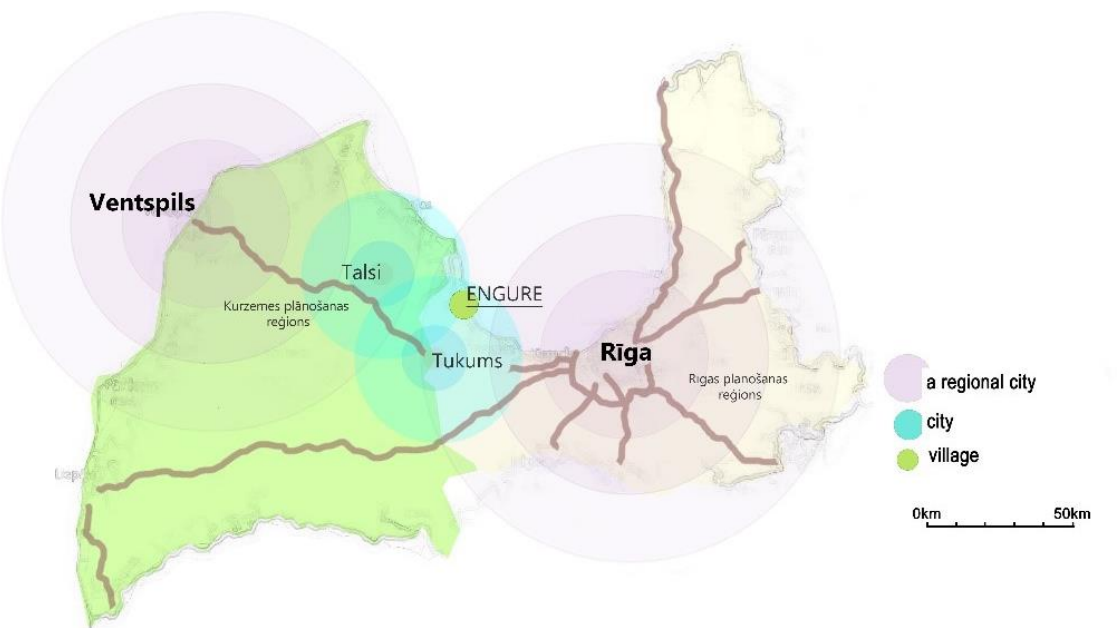

Fig. 1. Engure village on the map of Latvia [created by the authors]

The public open space is an integral part of the structure of the populated area, an integral part of the physical environment, which can also provide a positive increase of the factors affecting a social and economic environment in the populated area [12].

The public open space has been studied in the world extensively. It has become one of the topical themes among urban planners, architects and landscape architects in recent decades. The first public open space researches were carried out in the middle of the $20^{\text {th }}$ century, and as well-known researchers of the public open space are Jane Jacobs, Jan Gehl and William H. Whyte [5]. Researches of the public open space in Latvia were made relatively small, although the processes of its design and development happen every day. In regard to the coastline in the field of the landscape architecture there has been conducted a research on the identity of the coastal landscape of the Baltic Sea so far [13]. Studies on the public open space on a Latvian scale are mainly made on a city scale and on the field of spatial planning. One of the most comprehensive and largest research about the public open space has been carried out to Riga - "Development of the guidelines for the provision of greening structures and public open space networks in Riga" (2014-2015) [14].

Both in Latvia and in the world the public open space is rarely considered as an important part of rural (populated) areas. Rural areas of Latvia are becoming less populated in recent years, influenced by both social and economic conditions and urbanization processes in general. The quality of the public open space as one of the tools for improving the quality of the living environment can be a significant factor contributing to the return of the population to rural villages and cities.

Engure village on the West Coast of the Gulf of Riga was selected as a research object. The coastal landscape and the historically developed cultural environment is one of the fundamental aspects that characterizes not only Engure village and its public open space, but also the identity of the coastal landscape and environment of Latvia. It is a landscape rich of folk traditions and historical events, with coastal fishing villages and small towns were developed in the $19^{\text {th }}$ and $20^{\text {th }}$ centuries as economically developed coastal areas, today have become an integral part of the coastal landscape and a significant part of the structure of the populated areas for sustainable development of the country. The natural and cultural historical values of the place, geographical location and cultural heritage with folk traditions make Engure as a potential final destination for holiday or place of residence.

The purpose of the research is to analyze the public open space made structure of Engure village and its fundamental factors as functionality, quality and accessibility, as a result to understand the constituent factors of the surrounding factors and their characteristic criteria, the spatial structure created by the public open space in the populated area. As a result, defining the improvements of the structure of the public open space of the village as a means of promoting the quality of the living environment and positively affecting the social and economic aspects of the populated area.

\section{Objects}

Engure is located in the district of Engure and is one of the largest villages in the district and is a part of the Riga planning region. Engure is located $70 \mathrm{~km}$ from the capital of Latvia, Riga (Fig. 1). Engure is a district service center, crossed by a regional highway, the village has 1580 inhabitants [3], which has a tendency to increase during the summer season at the expense of holidaymakers.

The historical development of Engure dates back to the $2^{\text {nd }}$ half of the $13^{\text {th }}$ century - in 1245 the name of Engure was mentioned for the first time in the chronicles as a Liv settlement on the Lake of Engure. The economic and rapid development of the village is mainly related to the $17^{\text {th }}$ century - the reign of Duke Jacob. During this time extensive economic activities, trade and provision of export 


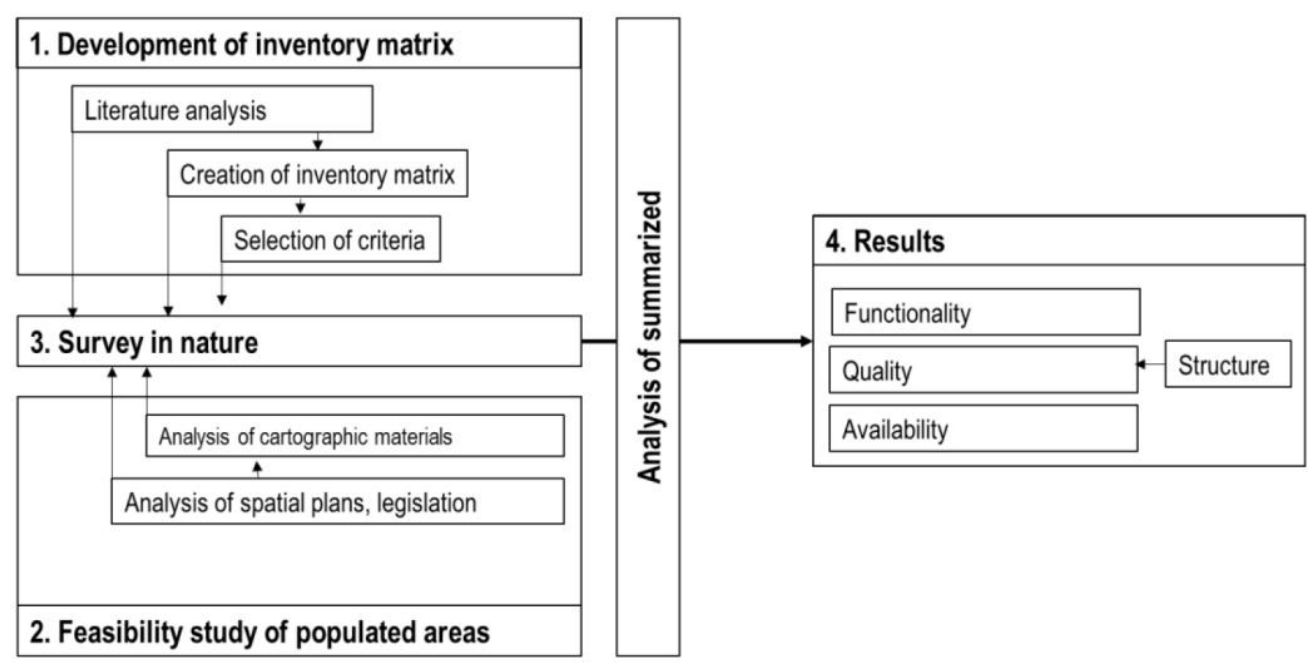

Fig. 2. The research process map [created by the authors]

services took place in the village, thus developing Engure as one of the small ports on the coast, for the needs of the Duchy of Courland [4].

Fish processing, fishing, parish administration, retail trade, logging and conversion and wood processing, agricultural production as the main areas of activity of the population are mentioned in the national economy. Historically the port should be mentioned as one of the largest and most important drivers of economic development. The port of Engure today has mainly become a tourist port, focusing on yachting tourism, docks of small fishing boats. The village has educational institutions such as kindergarten, high school, music and art school. Traditional cultural institutions as a folk house or cultural center, a meeting room with a museum, a library, a youth center. An important role in the cultural, tourism and recreation field of coastal villages has the traditional fishermen's festival, various art festivals, ancient fire nights, green balls that attract large number of visitors and guests in the summer season [3].

\section{Method}

In order to evaluate the public open space of Engure village, an overall assessment of its quality, availability, functionality and structure in the populated area, an inventory matrix was created and a survey in nature was conducted, aggregating 10 public open spaces in total. Excel software was used for analysis and interpretation of the gained data, results. The total period dedicated by the research is from autumn 2015 to spring 2017.

The research process is divided into 4 stages (Fig. 2), certain intermediate results were gained after the completion of each stage, which determined the beginning of the next stage. Each stage has to be done in sequence in order to carry out the next stage completely.
The research process can be divided into the following stages:

1. Selection of criteria characterizing the basic factors and sub-factors and creation of inventory matrix;

2. Feasibility study of populated areas;

3.Survey in nature;

4. Analysis of summarized data and results. Stage 1

The theoretical basis of research includes an analysis of scientific literature and monographs in order to understand the basic factors creating the public open space. On the basis of the defining fundamental factors forming the public open space, which are further subdivided into sub-factors, an inventory matrix is created and criteria are selected that characterize each of the sub-factors (Fig. 3).

The quality, availability and function of the public open space are defined as the key factors forming the public open space. According to the analysis of the scientific literature, the basic researched factors and the most appropriate criteria for the development of an inventory matrix were selected, derived from the methods applied in J. Gel and the PPS research, adapting them to the conditions of this research, identifying the factors to be investigated, which can be surveyed and inventoried in a short period of time in order to obtain a general but comparable view of the overall quality of the public open space.

\section{Stage 2}

In advance of performing the survey, in the process of feasibility study, it is necessary to identify the potentially surveyed public open spaces, their location and historical development, in order to be able to fully explore the place in nature and recognize the values of the place - landscape, cultural, historical, ecological. This was done by 


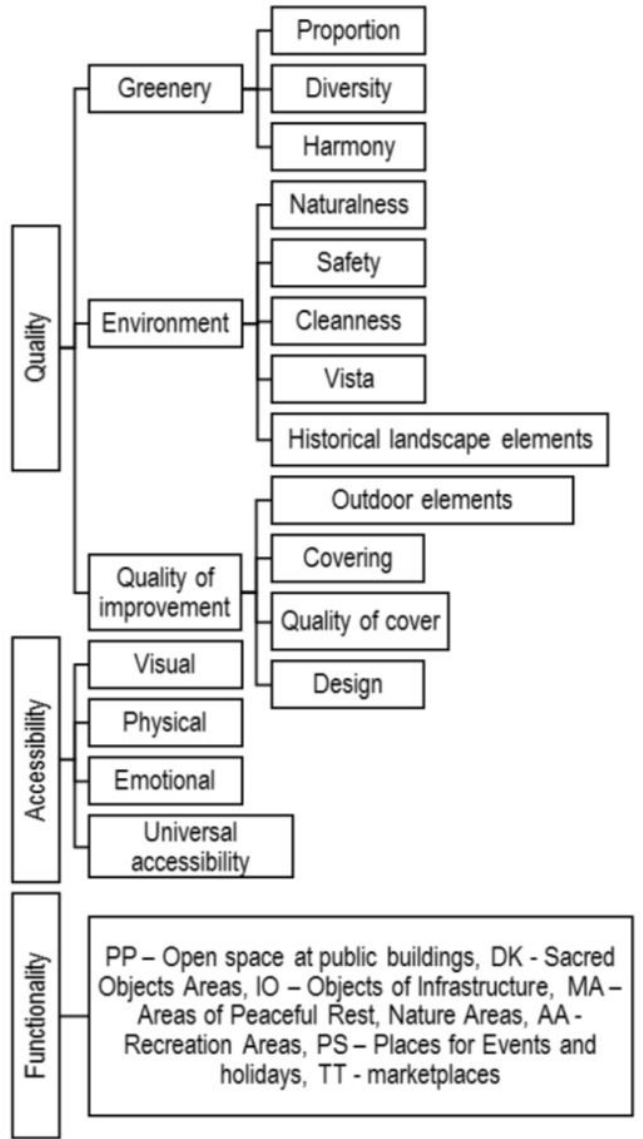

Fig. 3. Factors which forms public open space [created by the authors]

analyzing and exploring cartographic imagery of the populated area - a map, aerial photographs of the village, Google Street images, graphic materials and explanatory descriptions of the spatial planning of the district, available historical photographs and historical evidence in archives.

\section{Stage 3}

The observation was selected as a main research tool - a survey in nature, which helps to capture the social life of the public open space and form a set of its activities [5; 16]. In this way, all the data needed to complete the study inventory matrix are collected.

Being on the place, following the pre-mapped public open spaces, there were inventoried all areas freely accessible and visible from the main village streets or indicated by indication signs in the village. Such areas as parking lots - recreational areas, squares at public buildings, piers, freely accessible port areas, hiking trails, beach, open air estates, areas near the churches, marketplaces were surveyed in the research.

The inventory matrix was filled on site assigning a certain number of points to each of the underlying sub-factor according to the given criteria. In order to obtain an evaluation of the public open space, subfactors (greenery, environment, quality of improvement, visual, physical, emotional, universal accessibility) for each basic factor (quality, accessibility, functionality) are distinguished, which, according to its characteristic features, are evaluated for a point on a scale from 0 to 4 , giving it the appropriate clause for a point value or critera (Table 1; Table 2).

By evaluating the function of the public open space, they are identified by type, thus defining the basic function of the open space. Open spaces are divided by type according to the functional open types created by S. Carr [2]. By adjusting and combining types according to the types of open spaces found in villages, the following functional modes of the open space are distinguished in research: $\mathrm{PP}-$ Open space at public buildings, DK - Sacred Objects Areas, IO - Objects of Infrastructure, MA - Areas of Peaceful Rest, Nature Areas, AA - Recreation Areas, PS - Places for Events and holidays, TT - marketplaces. By the graphical analysis method, analyzing and mapping the location and functionality of the public open space in the village, a map of the structure of the public open space was created. It maps the surveyed public open spaces by their functional division and deplores the area of the central part of the village of $1 \mathrm{~km}^{2}$, determined on the basis of the amount and type of the public open space, defining village service centers.

In addition, during the process of the survey, a photo fixation of the place was made and the public open space was marked on the previously prepared aerial photography of the village. The survey of the public open space for Engure village was made within one day.

\section{Results}

\section{Functionality}

A map of the structure of the public open space was created by examining, analyzing and mapping the location and functionality of the public open space in the village (Fig. 4). It maps the surveyed public open spaces by their functional division and deplores the area of the central part of the village of $1 \mathrm{~km}^{2}$, determined on the basis of the amount and type of the public open space, defining village service center, which plays an important role in the development of sustainable and balanced populated area and in the development of place of economic, social, cultural activities and public interest of a certain area [1].

The structure of Engure village is characterized by a distinctly centric construction, arranged by public open spaces of various functions, such as open spaces at public buildings, infrastructure objects, events, holidays and market areas, in the central part, within a short distance from each other. In the outskirts of the village, creating areas of peaceful rest, nature areas, which is explained by the existing spatial plan of the village - the development 
Characteristic features of public open space quality [created by the authors]

\begin{tabular}{|c|c|}
\hline \multicolumn{2}{|c|}{ Quality (max -37 points) } \\
\hline Characteristic feature & Points - criteria \\
\hline \multicolumn{2}{|c|}{ Greenery (max - 10 points ) } \\
\hline Proportion & $\begin{array}{l}4 \text { - More than half of the territory consists of greenery or natural base; } 3 \text { - Less than half } \\
\text { of the territory consists of greenery or natural base; } 2 \text { - Less than } 1 / 4 \text { of the territory } \\
\text { consists of greenery or natural base; } 1 \text { - Less than } 1 / 10 \text { of the territory consists of } \\
\text { greenery or natural base. }\end{array}$ \\
\hline Diversity & $\begin{array}{l}\text { 3-The diversity and richness of the plant species, plant species typical of the region; } 2 \text { - } \\
\text { Small variety of plant species, plant species suitable for the region; } 1 \text { - The diversity and } \\
\text { richness of the plant species that are not characteristic of the region. }\end{array}$ \\
\hline Harmony & $\begin{array}{l}\text { 3- Greenery are in harmony with the environment; } 2 \text { - Greenery are interconnected, but } \\
\text { not in harmony with the environment; } 1 \text { - Greenery are made chaotic and unprofessional } \\
\text { or non-functional or Not specially made greenery / natural base. }\end{array}$ \\
\hline \multicolumn{2}{|c|}{ Environment ( $\max -15$ points) } \\
\hline Naturalness & $\begin{array}{l}3 \text { - Semi-natural or natural environment with minimal infrastructure; } 2 \text { - An environment } \\
\text { similar to the urban environment; } 1 \text { - Erosion-affected, degraded area or degraded } \\
\text { environment. }\end{array}$ \\
\hline Safety & 3- Safe; 2- Insecure in certain cases or groups of society; 1- Insecure. \\
\hline Cleanness & $\begin{array}{l}\text { 3- Clean environment, there are waste containers and urns; } 2 \text { - There is no waste } \\
\text { containers or urns, but the place is not dirty; } 1 \text { - Dirty environment. }\end{array}$ \\
\hline Vista & $\begin{array}{l}3 \text { - Expressive and beautiful landscape views or surrounding; } 2 \text { - There are no beautiful } \\
\text { views, but the surroundings are attractive and pleasant, well-organized; } 1 \text { - Views and the } \\
\text { environment around is degraded or is not pleasant or there are potentially landscape-rich, } \\
\text { sight-seeing views that are hidden. }\end{array}$ \\
\hline \multicolumn{2}{|c|}{ Quality of improvement (max -12 points) } \\
\hline Outdoor elements & $\begin{array}{l}3 \text { - All kind of necessary outdoor elements; } 2 \text { - Almost all kind of necessary outdoor } \\
\text { elements; } 1 \text { - There is no required outdoor elements. }\end{array}$ \\
\hline Covering & $\begin{array}{l}\text { 3- Separate pedestrian, cycling and road transport zones; } 2 \text { - Separate pedestrian and car } \\
\text { parking area, but no separate bicycle path; } 1 \text { - There are no separate pedestrian, cycling } \\
\text { and road vehicle zones. }\end{array}$ \\
\hline Quality of cover & $\begin{array}{l}3 \text { - Functional, good quality, coherent design; } 2 \text { - Functional but not qualitative or non- } \\
\text { functional and qualitative; } 1 \text { - There is no appropriate cover quality and functionality. }\end{array}$ \\
\hline Design & $\begin{array}{l}\text { 3- Interconnected outdoor elements, in harmony with the environment; } 2 \text { - Interconnected } \\
\text { outdoor elements, but not in harmony with the environment; } 1 \text { - The elements of the } \\
\text { improvement do not have a uniform design. }\end{array}$ \\
\hline
\end{tabular}

Characteristic features of public open space accessibility [created by the authors]

\begin{tabular}{|l|l|}
\hline Accessibility (max - 12 points) \\
\hline Characteristic feature & Points - criteria \\
\hline Visual & $\begin{array}{l}\text { 3- The territory is visible and easy to see from the main street of the village; 2- The } \\
\text { territory is not visible from the main street of the village, but there is a visible sign on the } \\
\text { street, which guide to the place; 1- The territory is to be seen only in the immediate } \\
\text { vicinity. }\end{array}$ \\
\hline Physical & $\begin{array}{l}\text { 3- The area is easily accessed by both pedestrians and cyclists and by car. There is } \\
\text { connection to the main street of the village; 2- The area is easily accessed by both } \\
\text { pedestrians and cyclists and by car. There is no connection to the main street of the } \\
\text { village; 1- The area is accessible only to pedestrians and cyclists. It is impossible to drive } \\
\text { by car. There is no place for parking. }\end{array}$ \\
\hline Emotional & $\begin{array}{l}\text { 3- The area is freely available and inviting; 2- The territory is freely available only to a } \\
\text { specific group of people; 1- The territory is freely accessible but not encouraging or it is } \\
\text { unclear whether the territory is freely available or not. }\end{array}$ \\
\hline Universal accessibility & $\begin{array}{l}\text { 3- Available to everyone, it is multifunctional and thoughtful about all groups of society; } \\
\text { 2- The place is not accessible to people with disabilities but is accessible to other groups }\end{array}$ \\
\hline
\end{tabular}


Assessment of the quality and accessibility of public open space [created by the authors]

\begin{tabular}{|c|c|c|c|}
\hline \multirow{4}{*}{ 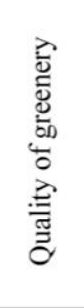 } & Assessment & Points & Valuation \\
\hline & LOW & $3-5$ & $\begin{array}{l}\text { The proportion of greenery in the area is less than } 1 / 4 \text { and mainly consists of a few } \\
\text { local plant species or broadly decorated plantations that do not harmonize with the } \\
\text { environment and landscape. }\end{array}$ \\
\hline & MEDIUM & $6-8$ & $\begin{array}{l}\text { Approximately half of the area is covered with greenery - a small variety of indigenous } \\
\text { plant species that form harmony with the environment and fits into the landscape. }\end{array}$ \\
\hline & GOOD & $9-10$ & $\begin{array}{l}\text { Most of the territory consists of greenery, plant species typical of the local area, or } \\
\text { skilled and successfully planed greenery. }\end{array}$ \\
\hline \multirow{3}{*}{ 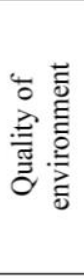 } & LOW & $5-7$ & $\begin{array}{l}\text { The environment is disordered and chaotic or even degraded, and therefore unsafe. It } \\
\text { has a potentially valuable landscape, scenic views, or cultural and historical elements } \\
\text { in it. But their presence in the territory is not visible and accentuated. }\end{array}$ \\
\hline & MEDIUM & $8-11$ & $\begin{array}{l}\text { The environment is clean and tidy, enjoyable, similar to the urban environment, thus } \\
\text { losing some of the identity of the coastal village. There are cultural and historical } \\
\text { elements in the territory, but they are not emphasized or highlighted. }\end{array}$ \\
\hline & GOOD & $12-15$ & $\begin{array}{l}\text { The environment is inherent or semi-natural, safe, landscape-rich, with the presence } \\
\text { of cultural and historical elements as main dominations in site. }\end{array}$ \\
\hline \multirow{3}{*}{ 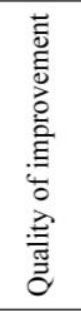 } & LOW & $4-7$ & $\begin{array}{l}\text { The territory is not well-developed, its functional zoning and infrastructure is not } \\
\text { organized. There is no consistent quality of the surface, as well as the design of the } \\
\text { outdoor elements. }\end{array}$ \\
\hline & MEDIUM & $8-9$ & $\begin{array}{l}\text { The area is partially landscaped with minimal, functional infrastructure. The quality } \\
\text { of surface is sufficient. Improvement elements and the design of the pavement are not } \\
\text { in harmony with the environment. }\end{array}$ \\
\hline & GOOD & $10-12$ & $\begin{array}{l}\text { The area is well-equipped with a convenient and well-organized infrastructure. The } \\
\text { quality of the surface is good and the design of the elements of the amenities is } \\
\text { harmonious and in harmony with the surrounding environment. }\end{array}$ \\
\hline \multirow{3}{*}{ 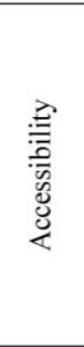 } & LOW & $4-6$ & $\begin{array}{l}\text { Place can be seen only when it is in close proximity and accessible only to pedestrians. } \\
\text { From the point of view of emotional perception, it is unclear whether it is freely } \\
\text { accessible, or restricted, and is only available to certain groups of the population. }\end{array}$ \\
\hline & MEDIUM & $7-9$ & $\begin{array}{l}\text { The place is not visible from the main village street, but there is a noticeable, attention- } \\
\text { grabbing reference to the place. There is a possibility that there is no convenient road } \\
\text { network connecting to the main village street. From a perceptive point of view, the } \\
\text { area is freely accessible but not encouraging. It is not accessible to people with } \\
\text { disabilities. }\end{array}$ \\
\hline & GOOD & $10-12$ & $\begin{array}{l}\text { The area is visible from the main village street and is accessible to all sections of the } \\
\text { community, whether on foot or by car or bicycle. It is freely available and inviting. }\end{array}$ \\
\hline
\end{tabular}

and location of residential areas, as well as the existing natural base, its values. As the most common types of public open spaces in Engure there are - open space at public buildings, infrastructure objects and areas of peaceful rest, nature areas.

\section{Quality}

In evaluating the quality of the public open space in the village, the low-quality assessment in Engure is in assessment of the sub-factors of the improvement and greenery, but the quality of the environment is assessed as medium. Analyzing the assessment matrix of Engure village (Table 4) and diagrams (Fig. 5), it is seen that the quality assessments of the greenery of each individual open space have split up into similar parts $-30 \%$ of the surveyed open spaces in Engure are evaluated with good and medium quality of greenery, but almost half $-40 \%$ low. The low greenery quality is rated for the following public open spaces: Southern Mall, the dock of the yacht port, market, and stadium. The assessment is considered to be partially appropriate, as the Southern Mall and the dock of the yacht port are considered to be industrial or infrastructure objects whose greenery is not essential first of all and does not affect the quality of the whole. On the other hand, the greenery located on the market, located in mobile boxes, is considered to be inappropriate (species selection), but around the stadium it would be advisable to place a group of protective greenery which would shelter territory from wind. Half of the surveyed public open spaces in Engure are of low quality, and only $20 \%$ of open spaces are considered to be of good quality. Such public open spaces as the parking lot near the church, the South Mole, the dock of the yacht port, the market, the area near the meeting house have low improvement quality.

The low assessment is the reason of the lack of elements of improvement in place to ensure the full and comfortable use of the place, as well as the poor quality of the condition of the surface and the design coherence for both the surface and the elements of the improvement.

In the environmental quality, $80 \%$ of the surveyed open space is rated as medium, which is assessed as well-tended and clean, but the potentially valuable elements of the place are not interfaced with it - hidden valuable landscape views or uncovered elements of cultural and historic significance in the village landscape. 


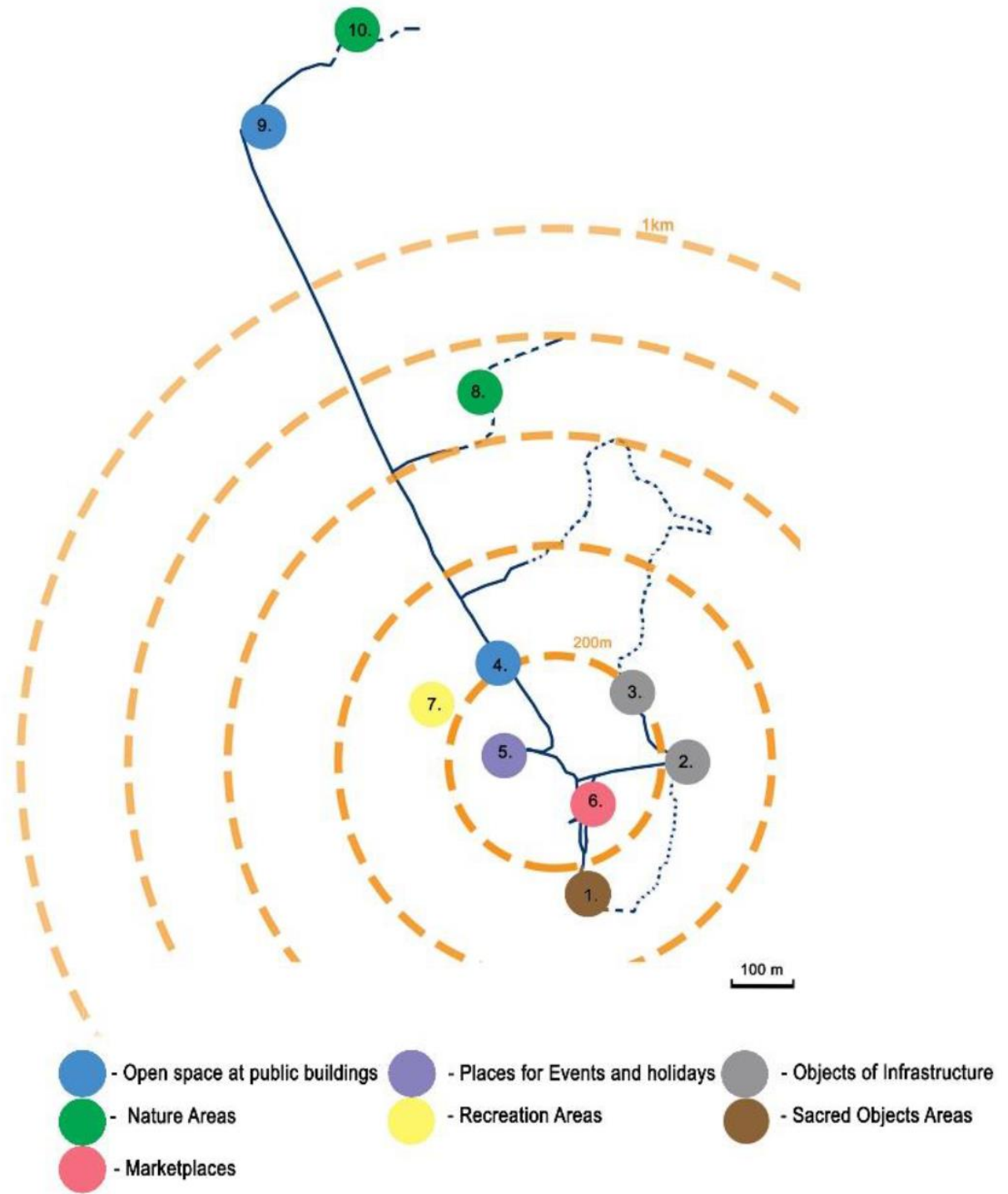

Fig. 4. Public opne space structure in engure [created by authors]

1 -Parking and church; 2 - Mole; 3 - Harbor; 4 -Square; 5 - Bandstand; 6-Market; 7 -Stadium; 8 / 10 - Hiking trail and beach; 9 - Meeting house

Assessment of the quality of public open space [created by the authors]

\begin{tabular}{|c|c|c|c|c|}
\hline & 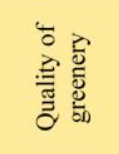 & 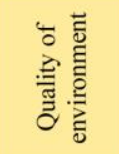 & 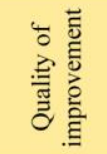 & 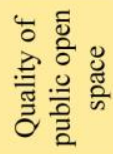 \\
\hline 1. Parking and church & medium & medium & low & medium \\
\hline 2. Mole & low & medium & low & low \\
\hline 3. Harbor & low & medium & low & low \\
\hline 4. Square & medium & medium & medium & medium \\
\hline 5. Bandstand & good & medium & medium & medium \\
\hline 6. Market & low & medium & low & low \\
\hline 7. Stadium & low & medium & medium & medium \\
\hline 8. Hiking trail and beach & good & good & good & good \\
\hline 9. Meeting house & medium & medium & low & medium \\
\hline 10. Hiking trail and beach & good & good & good & good \\
\hline
\end{tabular}




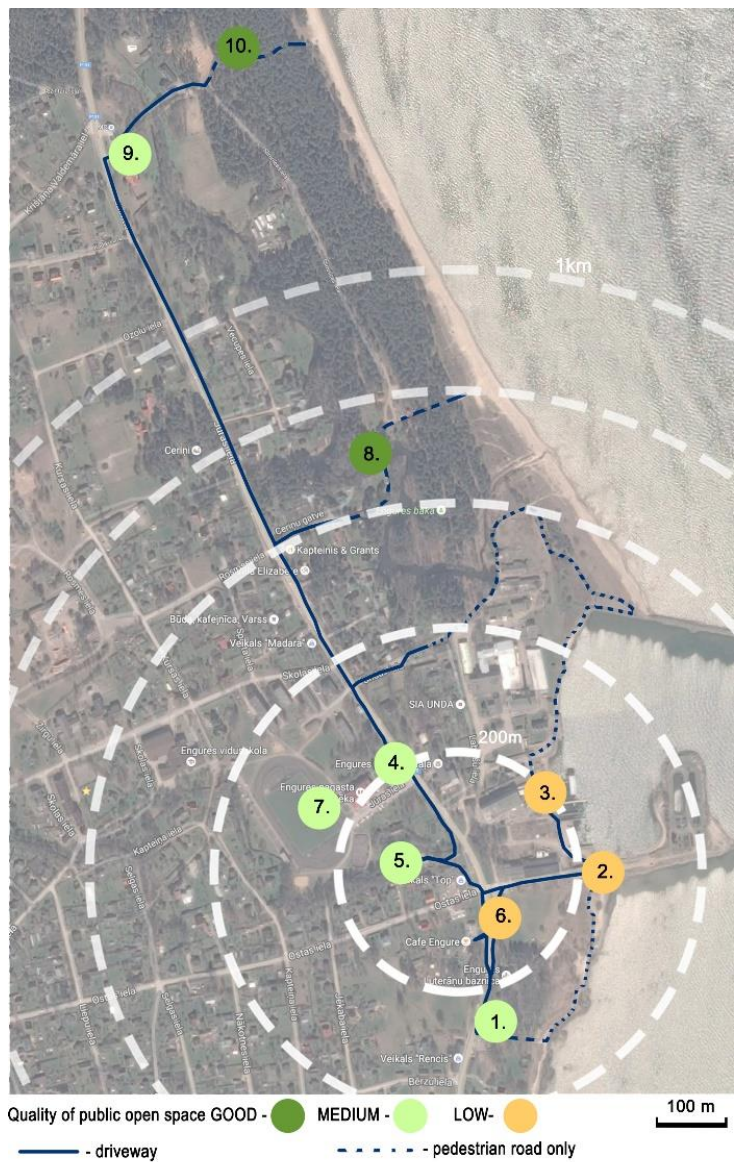

Fig. 5. Public open space quality diagrams [created by authors] 1 -Parking and church; 2 - Mole; 3 - Harbor; 4 - Square; 5 Bandstand; 6-Market; 7 -Stadium; 8 / 10 - Hiking trail and beach; 9 - Meeting house

TABLE 5

Assessment of the accessibility of public open space [created by the authors]

\begin{tabular}{|c|c|c|c|c|c|}
\hline & $\begin{array}{l}\overline{\underline{g}} \\
\overline{3} \\
\frac{3}{2}\end{array}$ & 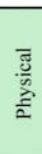 & 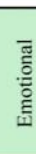 & 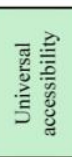 & 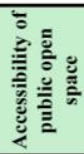 \\
\hline 1. Parking and church & 3 & 3 & 1 & 2 & medium \\
\hline 2. Mole & 1 & 3 & 1 & 2 & medium \\
\hline 3. Harbor & 1 & 3 & 1 & 2 & medium \\
\hline 4. Square & 3 & 3 & 3 & 3 & good \\
\hline 5. Bandstand & 2 & 1 & 3 & 1 & medium \\
\hline 6. Market & 3 & 3 & 3 & 3 & good \\
\hline 7. Stadium & 2 & 2 & 1 & 1 & low \\
\hline 8. Hiking trail and beach & 2 & 1 & 3 & 2 & medium \\
\hline 9. Meeting house & 3 & 3 & 2 & 2 & good \\
\hline 10. Hiking trail and beach & 2 & 3 & 3 & 2 & good \\
\hline
\end{tabular}

\section{Accessibility}

On evaluating the availability of the public open space of Engure village gained results shows that $80 \%$ of the universals, physical and visual availability of the surveyed open spaces are good or medium. The emotional approach has the lowest of accessibility rating / valuation. Half of the surveyed open spaces has an emotional a vailability of good,

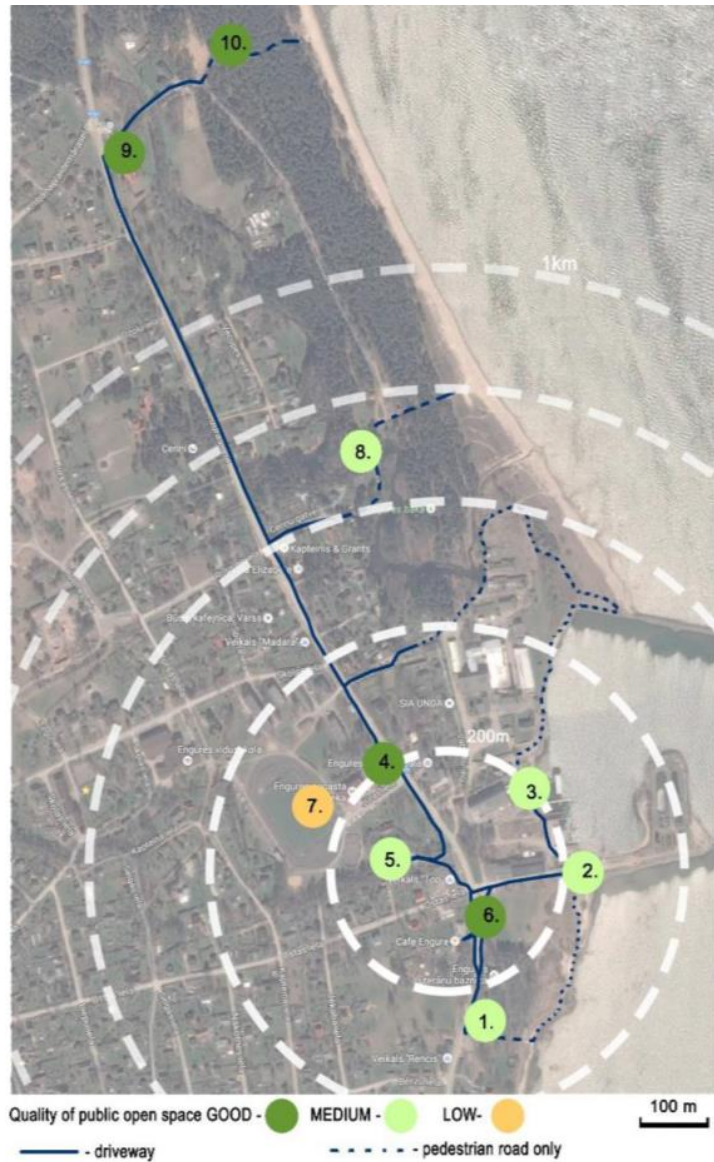

Fig. 6. Public open space accsesibility diagrams [created by the authors]

1 -Parking and church; 2 - Mole; 3 - Harbor; 4 - Square; 5 Bandstand; 6-Market; 7 -Stadium; 8 / 10 - Hiking trail and beach; 9 - Meeting house

$10 \%$ medium, but $40 \%$ of the open spaces is low, i.e. a parking lot near the church and the church area, the Southern Mall, the dock of the yacht port and the stadium. However, after the total number of points, these individual low values are offset by good values and, as it is seen in the availability matrix of Engure village (Table 5), and the mapping schema of the availability assessment (Fig. 5), that the low availability quality was obtained only for the stadium

The first three of the low ratings are because of the functional layout of the place or the elements of the improvement. Of course, the church is freely available to all inhabitants, but it is located behind a small fence and large gates - visually hardly noticeable, as large trees are grown around it, and without adequate fore and improvement, there is a feeling that it is better not to stay in this place and guests are not invited. Port territory is a private property and although the physical availability of moles and the port area is freely accessible, it is not clear whether this is allowed or not allowed to stay free of charge. Also, the visual accessibility of these two objects is considered low, because the place is 
almost invisible of the main village street. The sight of this is obscured by the industrial building of the port. Similarly, the quality of the surface of the stadium and the playing field is low - inappropriate for sporting activities, the only seats are arranged in the stands, the place is not accessible to people with special needs.

\section{Conclusion}

Researching the functionality and location structure of the public open space of Engure village there is a clearly defined central part of the village with public open spaces such as a port area, stage, square near a cultural house, stadium, and church area with a parking lot near the sea.

The quality of the public open space in Engure village is assessed as medium, with a tendency to poor quality of improvement and greenery, which would be prime improvement indicators to increase the overall quality of the public opens space in Engure village. On the other hand, the accessibility of the public open spaces of the village is considered good. Such an assessment is determined by the proximity of the public open spaces to the main street of the village, which ensures their availability or visibility. In cases where the open space is not located in immediate proximity to the street, signs of information indicate them.
Obtained results of the quality and accessibility assessment can be applied for purposeful management and maintenance of existing public open spaces. Based on assessments of quality, availability and functionality, cartographic and graphic materials as primary improving public open spaces in the village there are defined:

- Areas in the center of a village with low availability or quality rating.

- Areas of a village with a low availability or quality rating.

- Areas in the center of a village with a medium accessibility or quality rating.

- Areas of a village with a medium availability or quality rating.

Obtained results of the research can be applied in practice, planning work in local municipalities - in the arrangement of the public open spaces in populated areas. Detailed analyzing the evaluation matrix of each public open space and its results, understanding the reasons for the low evaluation and their possible solutions, which are divided into short-term and long-term works.

The obtained results of quality and accessibility, functionality assessment and graphical materials obtained as a result of analysis can be applied for purposeful management and maintenance of existing public spaces, planning of new public open spaces.

\section{References}

1. Briṇkis J., Buka O. Reǵionālā attīstība un prognostika pilsētplānošanas kontekstā. Rīga, 2008, 194 lpp.

2. Carr, S., Francis, M., Rivlin, L. G., \& Stone, A. M. Public space. Cambridge: Cambridge University Press, 1992, Vol. 40, $400 \mathrm{p}$.

3. Engures novada teritorijas plānojums (The spatial planning of the district of Engure) [online 15.01.2017.] http://www.enguresnovads.lv/uploads/filedir/terit_planojums/Paskaidrojuma_raksts.pdf

4. From the archive of the museum of Engure.

5. Gehl, J. Svarre, B. How to Study Public Life. Washington, DC: Island Press, 2013. 179 p.

6. Gehl, J., \& Gemzøe, L., Public Spaces, Public Life: Copenhagen. $3^{\text {rd }}$ ed. Copenhagen: Danish Architectural Press \& the Royal Danish Academy of Fine Arts, School of Architecture Publishers, 2004. 96 p.

7. Giles-Corti, B., Broomhall, M. H., Knuiman, et.at. Increasing Walking. How Important Is Distance To, Attractiveness, and Size of Public Open Space? American Journal of Preventive Medicine, 2005, Vol. 28, p. 169-176.

8. Herzele, A. Van, \& Wiedemann, T. A monitoring tool for the provision of accessible and attractive urban green spaces. Landscape and urban planning. Elsevier: 2003, Vol. 63, p 109-126. ISSN 0169-2046

9. Jalaladdini, S. Oktay, D. Urban Public Spaces and Vitality: A Socio-Spatial Analysis in the Streets of Cypriot Towns. Procedia - Social and Behavioral Sciences. Elsevier: 2012, Vol. 35, p. 664-674.

10. Kianicka, S., Buchecker, M., Hunziker, M., \& Müller-Böker, U. Locals' and tourists' sense of place: A case study of a Swiss Alpine village. Mountain Research and Development, 2006, No. 26 (1), p. 55-63.

11. Leng, H., \& Li, T. Research on Public Open Space of Rural Areas in Severe Cold Regions Based on Survey of Residents on the Behavioral Activity. Procedia Engineering. Elsevier: 2016, Vol. 146, p. 327-334.

12. Nasution, A. D., \& Zahrah, W. Community Perception on Public Open Space and Quality of Life in Medan, Indonesia. Procedia - Social and Behavioral Sciences. Elsevier: 2014, Vol. 153, p. 585-594.

13. Nitavska, N. The Baltic Sea coastal landscape identity in Latvia. Ph.D. thesis. Latvia University of Agriculture, 2014. 128 p.

14. Vadlīniju izstrāde apstādījumu struktūras un publisko ārtelpu tīklojuma nodrošināšanai Rīgā: (Development of the guidelines for the provision of greening structures and public open space networks in Riga) [online 20.10.2016.] http://www.sus.lv/sites/default/files/media/faili/ii_sejums_petijums_vadliniju_izstrade_apstadijumu_strukturas_un_p ublisko_artelpu_tiklojuma_nodrosinasanai_riga.pdf

15. Vispārīgie teritorijas plānošanas, izmantošanas un apbūves noteikumi (General spatial planning, use and building regulations) [online 17.11.2016.]. https://likumi.lv/doc.php?id=256866

16. What makes a successful place? [online] Project for public spaces [cited 20.10.2015.]. https://www.pps.org/reference/grplacefeat/ 
INFORMATION ABOUT AUTHORS:

Anna Kalniņa - Lector at Latvia University of Agriculture, Faculty of Environment and Civil Engineering, Department of Landscape architecture and Planning. E-mail: anna.kalnina@llu.lv

Natalija Nitavska - Asoc. professor at Latvia University of Agriculture, Faculty of Environment and Civil Engineering, Department of Landscape architecture and Planning. E-mail: natalija.nitavska@1lu.lv

Kopsavilkums. Pasaulē publiskās ārtelpas loma un nozīme pilsētu un apdzīvoto vietu kontekstā aizvien pieaug un kḷūst nozīmīga gan saistīto jomu profesionāḷu, gan iedzīvotāju vidū. Arī Latvijā šīs tēmas aktualitāte pēdējo gadu laikā ir palielinājusies. Publiskā ārtelpa ir viens no nozīmīgākajiem dzīves vides kvalitātes raksturojošajiem aspektiem, kas ietekmē vietas ekonomiskos un sociologiskos faktorus. Publiskās ārtelpas kvalitāte vērtējama kā svarīgs urbānās vides faktors, jo pati publiskā ārtelpa ir viens no šīs vides ainavas struktūras galvenajiem pamatelementiem, kas var būt nozīmīgs ietekmējošais faktors, lai veicinātu iedzīvotāju atgriešanos lauku rajonu ciemos un pilsētās. Tā veido vietas identitāti un raksturo sabiedrību, kas to veido un tajā uzturas. Pētījumā vērtēta Engures ciema publiskās ārtelpas. Engures ciems ir viens no Latvijas piekrastes zvejniekciemiem, kas veidojies 13. gs. 2. pusē, vēlāk attīstoties kā viens no mazo ostu ciemiem Rīgas jūras līča rietumu piekrastē. Engurē dzīvo ap 1500 iedzīvotāju, bet vasaras sezonā ciems kḷūst par iecienītu tūristu un atpūtnieku galamērḳi. Piekrastes ainava un vēsturiski veidojusies kultūrvide raksturo ne tikai Engures ciematu, un tās publisko ārtelpu, bet arī Latvijas piekrastes ainavas un vides identitāti. Tā ir tautas tradīciju un vēsturisku notikumu bagāta ainava ar piekrastes zvejniekciemiem un mazām pilsētām, kas 19. un 20. gadsimtā veidojās kā ekonomiski attīstītākās piekrastes vietas, šodien kḷuvušas par neatṇemamu piekrastes ainavas elementu un nozīmīgu apdzìvoto vietu struktūras sastāvdaḷu ilgtspējīgai valsts attīstībai. Vietas dabas un kultūrvēsturiskās vērtības, ǵeogrāfiskais novietojums un kultūras mantojums ar tautas tradīcijām, Enguri veido kā potenciālu brīvdienu atpūtas vai dzīves vietas galamērķi. Pētījumā izmantojot salīdzinošo metodi zinātniskās literatūras analīzei, tika noteikti publiskās ārtelpas veidojošie pamatfaktori un atlasīti pamatkritēriji ārtelpas kvalitātes, pieejamības un funkcionalitātes novērtējumam. Veicot ciema publisko ārtelpu novērtējumu, iegūtie rezultāti atspoguḷo Engures ciema publiskās ārtelpas kvalitāti, kuru raksturo vietas pieejamība, labiekārtojuma, apstādījumu un vides kvalitātes kopvērtējums. Iegūtos kvalitātes un pieejamības, funkcionalitātes novērtējuma rezultātus un analīzes rezultātā iegūtos grafiskos materiālus, iespējams pielietot mērķtiecīgai esošo publisko ārtelpu apsaimniekošanai un uzturēšanai, jaunu publisko ārtelpu plānošanai. Balstoties uz kvalitātes, pieejamības un funkcionalitātes novērtējumiem, kartoshēmām un grafiskajiem materiāliem iespējams definēt primāri uzlabojamās. 